\title{
Diversity change of microbial communities responding to zinc and arsenic pollution in a river of northeastern China ${ }^{* \#}$
}

\author{
Jun ZHAO ${ }^{1,2}$, Xin ZHAO ${ }^{\dagger 2,3}$, Lei CHAO ${ }^{2}$, Wei ZHANG ${ }^{2}$, Tao YOU ${ }^{2}$, Jie ZHANG ${ }^{\dagger 1}$ \\ ( ${ }^{1}$ State Key Laboratory of Urban Water Resources and Environment, School of Municipal and Environmental Engineering, \\ Harbin Institute of Technology, Harbin 150090, China) \\ ( ${ }^{2}$ Liaoning Academy of Environmental Sciences, Shenyang 110161, China) \\ $\left({ }^{3}\right.$ College of Resource \& Civil Engineering, Northeastern University, Shenyang 110004, China) \\ †E-mail: zhaoxin@mail.neu.edu.cn; 6282031@163.com \\ Received Jan. 4, 2014; Revision accepted May 23, 2014; Crosschecked June 19, 2014
}

\begin{abstract}
Pollution discharge disturbs the natural functions of water systems. The environmental microbial community composition and diversity are sensitive key indicators to the impact of water pollutant on the microbial ecology system over time. It is meaningful to develop a way to identify the microbial diversity related to heavy metal effects in evaluating river pollution. Water and sediment samples were collected from eight sections along the Tiaozi River where wastewater and sewage were discharged from Siping City in northeastern China. The main pollutants contents and microbial communities were analyzed. As the primary metal pollutants, zinc ( $\mathrm{Zn}$ ) and arsenic (As) were recorded at the maximum concentrations of 420 and $5.72 \mu \mathrm{g} / \mathrm{L}$ in the water, and 1704 and $1.92 \mathrm{mg} / \mathrm{kg}$ in the sediment, respectively. These pollutants posed a threat to the microbial community diversity as only a few species of bacteria and eukaryotes with strong resistance were detected through denaturing gradient gel electrophoresis (DGGE). Acinetobacter johnsonii, Clostridium cellulovorans, and Trichococcus pasteurii were the dominant bacteria in the severely polluted areas. The massive reproduction of Limnodrilus hoffmeisteri almost depleted the dissolved oxygen (DO) and resulted in the decline of the aerobic bacteria. It was noted that the pollution reduced the microbial diversity but the L. hoffmeisteri mass increased as the dominant community, which led to the overconsuming of DO and anaerobic stinking water bodies. Water quality, concentrations of heavy metals, and the spatial distribution of microbial populations have obvious consistencies, which mean that the heavy metals in the river pose a serious stress on the microorganisms.
\end{abstract}

Key words: River pollution, Microbial community diversity, Denaturing gradient gel electrophoresis (DGGE), Heavy metal, Zinc (Zn), Arsenic (As)

doi: 10.1631 jzus.B1400003

Document code: A

CLC number: X522

\section{Introduction}

With the rapid economic development over the past decades, China's industrialization has made a remarkable progress, but has also made the accompanied environment and ecosystems vulnerable by

\footnotetext{
¿ Corresponding author

* Project supported by the National Science and Technology Major Project of China (Nos. 2008ZX07208-005 and 2012ZX07202-003)

" Electronic supplementary materials: The online version of this article (http://dx.doi.org/10.1631/jzus.B1400003) contains supplementary materials, which are available to authorized users

(C) Zhejiang University and Springer-Verlag Berlin Heidelberg 2014
}

serious environmental pollution. Although the water quality of the seven largest river systems in China has gained improvement by vigorous remediation, quite a lot of small rivers or tributaries were still seriously polluted and urgently require more attention and governance (Yuan et al., 2012). The Tiaozi River, a second-level upstream tributary of the Liaohe River (one of China's seven largest river systems), has a total length of $78.6 \mathrm{~km}$ and a drainage area of $861 \mathrm{~km}^{2}$, and is the major water resource for agricultural irrigation (Yan et al., 2000; Gao et al., 2010). However, nearly 23 million tons of industrial 
wastewater and sewage generated by Siping City and amounts of surface runoff containing agricultural fertilizers were introduced annually into the river (Chen, 2009). About six years ago, the concentrations of chemical oxygen demand (COD) and $\mathrm{NH}_{4}^{+}$were detected as nearly 400 and $25 \mathrm{mg} / \mathrm{L}$, respectively (Chen, 2009; Chao et al., 2010; Gao et al., 2010). Even the groundwater was also polluted, and the heavy pollution seriously increased the risk of diseases to the locals (Jiang et al., 2002; Chen, 2009). Fortunately, after the operation of the Siping Sewage Treatment Plant and the shutdown of some highpolluting enterprises, the water quality of the Tiaozi River has been improved. However, the water quality is still far from harmless for agricultural production and human living, and fish, shrimp, and other aquatics are very scarce (Jiang et al., 2002; Yang et al., 2012; MEP, 2013).

Pollutants discharged into a river system are distributed between the aqueous phase and bed sediments (Sin et al., 2001). Because of adsorption, hydrolysis, and co-precipitation, some portions of free metal ions stay dissolved in water and most of them get deposited in the sediment (Gaur et al., 2005). Heavy metal residues in contaminated habitats may accumulate in microorganisms, aquatic flora, and fauna, which, in turn, may enter into the human food chain and threaten the well-being of the residents around the polluted river (Cooke et al., 1990; Deniseger et al., 1990).

Microorganisms, as an essential component of ecosystems, are involved in organic material degradation, nutrients release, biogeochemical cycling, and soil structure maintenance (Goberna et al., 2005; Tian et al., 2008; Brandt et al., 2010). However, the environmental microbial community composition, structure, and diversity were unclear until molecular approaches and fingerprinting techniques were applied to characterizing microbial species and assemblages. These new techniques significantly increased people's understanding of environmental microbial communities and the relationships between plants, animals, and other environmental factors (Green et al., 2008). Previous studies have reported that microorganisms are much more sensitive to a river's environmental factor changes than plants growing, and bacterial communities can be sensitive indicators for contaminant stress (Sun et al., 2012). Zhu et al. (2013) analyzed the sediment bacterial community composition polluted by multiple heavy metals in the Xiangjiang River of China using the polymerase chain reaction-restriction fragment length polymorphism (PCR-RFLP) method, and found that $\alpha$-Proteobacteria was one of the three remaining dominant families, and significantly increased with the increase of heavy metals. Garcia-Armisen et al. (2011) analyzed the total microbial community in the sewage-contaminated Zenne River in Brussels using a 16S rRNA clone library, and found that phyla Proteobacteria, Bacteroidetes, and phylum TM7 were the most represented antimicrobial heterotrophic bacteria. Virsek et al. (2013) investigated the development of pollution-induced community tolerance (PICT) by microorganisms in biofilms in the Hg-polluted Idrijca River in Slovenia through quantification of the merA gene. The results indicated that the biofilm communities in polluted environments are more static than planktonic communities and are strongly influenced by different mercury $(\mathrm{Hg})$ species. The catalyzed reporter deposition-fluorescence in situ hybridization (CARDFISH) and denaturing gradient gel electrophoresis (DGGE) were used to investigate the effects of antibiotics on biofilm bacterial communities in the Llobregat River (Northeast Spain), and Proia et al. (2013) found that the continuous admittance of antibiotics into river ecosystems led to significant changes in the microbial communities, in particular by favoring the antibiotic-resistant bacteria (Actinobacteria). Although the impact of river pollution on changes of microbial communities was closely monitored in recent years, China started relatively late, with little attention being devoted to heavily polluted small rivers or tributaries, and the diversity and structure of indigenous microbial populations within the special contaminated sediments are still unclear.

In the present study, the water quality, heavy metal concentrations, and microbial communities of the sediment samples collected from eight locations along the Tiaozi River were analyzed. Spatial variations of river pollution and sediment microbial communities were discussed. Eight different locations with typical pollution characteristics were helpful to infer the stress effects of heavy metals on the environmental microorganisms. The shock of the latest pollution of the Tiaozi River to its microbial community was also discussed to evaluate significant changes for further pollution control and protection. 


\section{Materials and methods}

\subsection{Sample collections}

Eight sampling points (SPs) were selected along the Tiaozi River (Fig. 1). The water apparent characteristics were quite different (Fig. 2). There were two SPs in the upstream of Siping City: one for the export of the Xiasantai Reservoir (SP1) and the other for its entrance into Siping City (SP2). SP1 (124'34'50.5" E/ $43^{\circ} 15^{\prime} 24.7^{\prime \prime} \mathrm{N}$ ) was $5 \mathrm{~m}$ in width and $0.2 \mathrm{~m}$ in depth with lush vegetation and infrequent human activities. The water was unpolluted and was of no odor. The bottom sand was clearly visible and some little fish

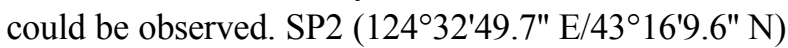
was in the outskirts of Siping City. SP2 had much vegetation (such as reeds) along both sides of the river; however, the water quality was affect by frequent human activities and direct wastewater discharge, and appeared as very yellowish in color.
The locations of four SPs were selected in the middle reaches of the river as follows: Siping City (SP3), Siping export (SP4), Yihetun (SP5), and the Tiaozi River Sewage Treatment Project (SP6). SP3 $\left(124^{\circ} 22^{\prime} 9.8^{\prime \prime} \mathrm{E} / 43^{\circ} 10^{\prime} 52.7^{\prime \prime} \mathrm{N}\right)$ was in the landscape river of Siping City (width about $60 \mathrm{~m}$ and depth $0.2-0.4 \mathrm{~m}$ ). There was no vegetation on either side of the river at SP3. The water was turbid and yellowish with serious odor and a slower flow rate. Dead wild fish were found in the shallow water, and some raised goldfish or koi were observed alive in the deep water. SP4 (1241 $\left.17^{\prime} 33.8^{\prime \prime} \mathrm{E} / 43^{\circ} 12^{\prime} 18.8^{\prime \prime} \mathrm{N}\right)$ was also in the outskirts of Siping City, but the river was at the very edge of the city. The water flew fast with a muddy yellow color and bad odor. On both sides of the riverbanks, there were a lot of garbage and construction waste. There was a lot of gray and black flocculent attached to the stones or dead branches that swung with the flow. A large amount of red tubifexes

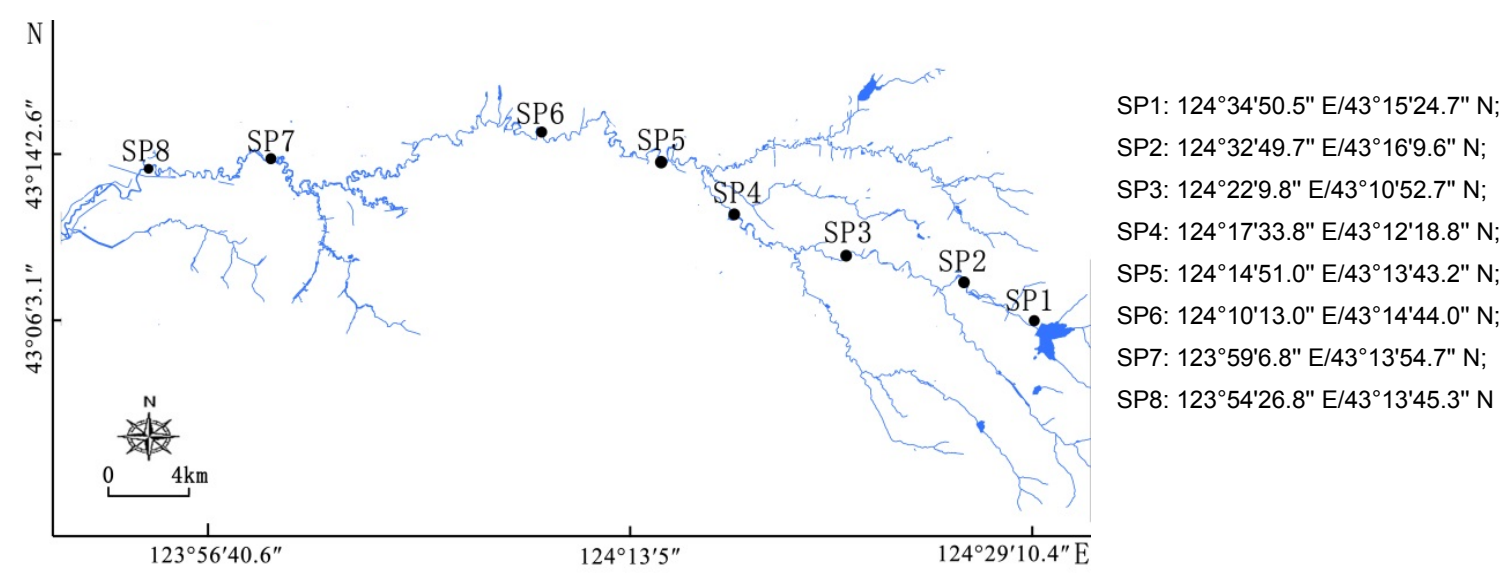

Fig. 1 Locations of sampling points (SPs) in the Tiaozi River, China

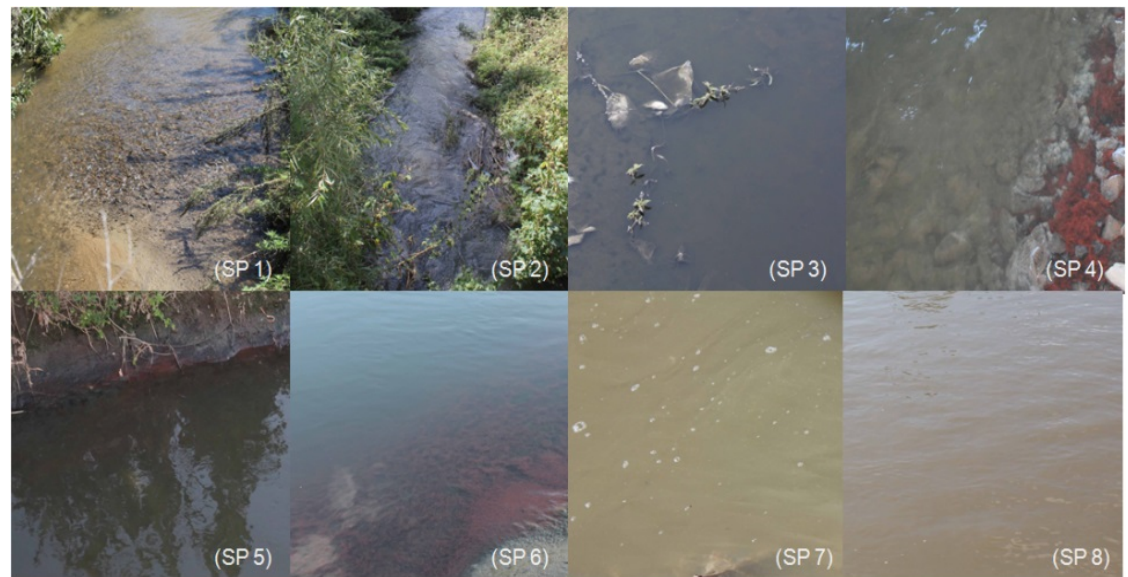

Fig. 2 Apparent characterization of different sampling points (SPs) in the Tiaozi River, China 
were observed in the sediment along both riverbanks. SP5 (124 $\left.{ }^{\circ} 14^{\prime} 51.0^{\prime \prime} \mathrm{E} / 43^{\circ} 13^{\prime} 43.2^{\prime \prime} \mathrm{N}\right)$ was at the provincial junction of Jilin and Liaoning Provinces, which was the most seriously polluted section, and the groundwater was also found to be contaminated. SP5 was $8 \mathrm{~m}$ in width and $1 \mathrm{~m}$ in depth, with a flow rate of $0.6 \mathrm{~m} / \mathrm{s}$. Flocks of tubifex were also observed in both riverbanks. An extremely thick layer of black precipitate was observed at the river bottom. The water was turbid, yellowish, and foul-smelling. SP6 $\left(124^{\circ} 10^{\prime} 13.0^{\prime \prime} \mathrm{E} / 43^{\circ} 14^{\prime} 44.0^{\prime \prime} \mathrm{N}\right)$ was downstream at a wastewater treatment demonstration project under construction, with a width of $7 \mathrm{~m}$, an average depth of $0.8 \mathrm{~m}$, and a low flow rate. Although there was an artificial water oxygen-rich segment at the upstream for SP6, the dissolved oxygen (DO) was still very low and the atmosphere was filled with an odor. On both sides of the riverbeds at SP6, there were more flocks of tubifex observed than those at SP5.

In the downstream reaches, there were two SPs, SP7 at the Yonghong Bridge and SP8 at the Qujia section. SP7 (123 $\left.59^{\prime} 6.8^{\prime \prime} \mathrm{E} / 43^{\circ} 13^{\prime} 54.7^{\prime \prime} \mathrm{N}\right)$ was at the Yonghong Bridge of Changtu County. This section was $10 \mathrm{~m}$ in width and $1.5 \mathrm{~m}$ in average depth. The water was yellow and cloudy, and the sediment was black. Tubifex was rarely observed at SP7. SP8 $\left(123^{\circ} 54^{\prime} 26.8^{\prime \prime} \mathrm{E} / 43^{\circ} 13^{\prime} 45.3^{\prime \prime} \mathrm{N}\right)$ was at the confluence of the Tiaozi River and the Zhaosutai River, which was $10 \mathrm{~m}$ in width and $0.9 \mathrm{~m}$ in depth with a flow rate of $1.07 \mathrm{~m} / \mathrm{s}$. No tubifex was observed. The high flow rate washed the sediment and the riverbeds, which resulted in a yellow and turbid water quality. According to the local people, the river water quality had been improved compared to previous years, and many kinds of aquatic organisms such as fish and shrimp could be found, but to safely use these aquatic organisms for food is still of great concern.

\subsection{Analysis of physico-chemical parameters}

COD, total nitrogen (TN), total phosphate (TP), and total content of heavy metals of chromium $(\mathrm{Cr})$, cadmium $(\mathrm{Cd})$, lead $(\mathrm{Pb}), \mathrm{Hg}$, arsenic (As), copper $(\mathrm{Cu})$, and zinc $(\mathrm{Zn})$ in the water and sediment samples were determined according to the standard methods (APHA, 1998). DO, $\mathrm{pH}$, and temperature were measured in situ using specific electrodes (Sension ${ }^{\mathrm{TM}} 156, \mathrm{HACH}, \mathrm{USA}$ ). The river's flow rate was determined by an OTTC20 velocity analyzer
(HACH, USA). The river sediment samples were collected from the middle of the channel at a depth of approximately $0-5 \mathrm{~cm}$, and were stored frozen for later microbial community analysis.

\subsection{DGGE analysis}

Genomic DNA extraction from the river sediment was carried out using a Power Soil DNA isolation kit (MOBIO, USA). The bacterial 16S rRNA gene was PCR-amplified using the primer pairs Bac 968 F (5'-AAC GCG AAG AAC CTT AC-3') and Univ1401 R (5'-GCG TGT GTA CAA GAC CC-3'), which were attached to a GC clamp (CGC CCG CCG CGC CCC GCG CCC GTC CCG CCG CCC CCG CCC G) for DGGE analysis (Ren et al., 2007). The PCR was programed as follows: initial denaturation at $94{ }^{\circ} \mathrm{C}$ for $5 \mathrm{~min} ; 30$ cycles at $94{ }^{\circ} \mathrm{C}$ for $1 \mathrm{~min}, 55^{\circ} \mathrm{C}$ for $30 \mathrm{~s}$, and $72{ }^{\circ} \mathrm{C}$ for $30 \mathrm{~s}$; decreasing $0.1{ }^{\circ} \mathrm{C}$ per cycle to $52^{\circ} \mathrm{C}$, and extension of incomplete products at $72{ }^{\circ} \mathrm{C}$ for $30 \mathrm{~min}$. The fragment of $18 \mathrm{~S}$ rRNA gene was amplified using the primer pairs NS1 (5'-GTA GTC ATA TGC TTG TCT C-3') and GC-Fung (5'-CGC CCG CGC CCC GCG CCC GGC CCG CCG CCC CCG CCC CAT TCC CCG TTA CCC GTT G-3') (May et al., 2001). The PCR was programed as follows: initial denaturation at $95{ }^{\circ} \mathrm{C}$ for $2 \mathrm{~min} ; 35$ cycles at $95^{\circ} \mathrm{C}$ for $50 \mathrm{~s}, 50^{\circ} \mathrm{C}$ for $50 \mathrm{~s}$, and $72{ }^{\circ} \mathrm{C}$ for $55 \mathrm{~s}$; and extension of incomplete products at $72{ }^{\circ} \mathrm{C}$ for $30 \mathrm{~min}$. The PCR products were examined by electrophoresis on a $1 \%(10 \mathrm{~g} / \mathrm{L})$ agarose gel.

DGGE was performed in a DCode ${ }^{\mathrm{TM}}$ universal mutation detection system (Bio-Rad, USA) as described by Ren et al. (2007). The PCR samples were applied directly to $80 \mathrm{mg} / \mathrm{ml}$ polyacrylamide gels in a $1 \times$ TAE buffer with a denaturing gradient ranging from $30 \%$ to $60 \%$. Denaturation of $100 \%$ corresponds to $7 \mathrm{~mol} / \mathrm{L}$ urea and $40 \%(\mathrm{v} / \mathrm{v})$ formamide. Electrophoresis was run at a constant voltage of $200 \mathrm{~V}$ and at $60{ }^{\circ} \mathrm{C}$ for $3.5 \mathrm{~h}$. The gel was stained with $\mathrm{AgNO}_{3}$ (Bassam et al., 1991). Prominent DGGE bands were selected and used for excision. The re-amplified products were purified and cloned by the pMD19-T plasmid vector system (TaKaRa, Dalian, China) for DNA sequencing (Zhao et al., 2012). The 16S rRNA gene sequences were aligned and identified against existing sequences in the GenBank database using the BLAST program. Neighbor-joining phylogenetic trees of $16 \mathrm{~S}$ and $18 \mathrm{~S}$ rRNA were constructed with the 
molecular evolutionary genetics analysis package (MEGA, Version 4.1) (Zhao et al., 2010).

\section{Results and discussion}

\subsection{Water chemistry changes and heavy metal pollution}

Fig. 3 and Table 1 show the water quality changes and seven heavy metals distributions in the water and sediment of the Tiaozi River, respectively. The concentrations of $\mathrm{Cr}, \mathrm{Cd}, \mathrm{Pb}, \mathrm{Hg}$, and $\mathrm{Cu}$ were low in different SPs, and concentrations of $\mathrm{Cd}, \mathrm{Pb}$, and $\mathrm{Cu}$ were below the detection limits in water. As the upstream river (SP1 and SP2) was located at mountainous or rural areas with little human activity and no industrial enterprises, the river water quality was in a good condition. The COD, TP, TN, and suspended solid (SS) concentrations were very low (about 10.0, 3.0, 0.5, and $40.0 \mathrm{mg} / \mathrm{L}$, respectively). The water was slightly alkaline with $\mathrm{pH}$ around 8.7 and DO about $6.0 \mathrm{mg} / \mathrm{L}$. Concentrations of heavy metals in the water and sediment were also low at the river source and upstream.

More human activities and industrial enterprises began to appear along the reaches after SP2, which significantly changed the water quality. The water was turbid and yellowish or gray with a serious odor. Concentrations of COD, TN, and TP significantly increased from SP3, reaching the maximum of $47.0 \mathrm{mg} / \mathrm{L}$ at SP4, $17.4 \mathrm{mg} / \mathrm{L}$ at $\mathrm{SP} 5$, and $6.93 \mathrm{mg} / \mathrm{L}$ at SP6, respectively, and then dropped significantly. The DO and $\mathrm{pH}$ were observed at the maximum at SP3 (13.5 mg/L and 9.1, respectively), and then declined significantly and reached the minimum of DO of $1.6 \mathrm{mg} / \mathrm{L}$ at SP5 and $\mathrm{pH} 7.8$ at SP4. The concentration of SS was below $65 \mathrm{mg} / \mathrm{L}$ and did not change too much between these reaches. Large amounts of red tubifexes were observed in the sediment along both riverbanks between SP4 and SP6, resulted from increasing organic pollutants. Concentrations of heavy metals also increased from SP3. The maximum concentrations of the seven heavy metals $(\mathrm{Cr}, \mathrm{Cd}, \mathrm{Pb}, \mathrm{Hg}$, $\mathrm{As}, \mathrm{Cu}$, and $\mathrm{Zn}$ ) in the sediment and two (As and $\mathrm{Zn}$ ) in the water were observed at SP4, and then gradually decreased in the following reaches (Table 1). The most organic and inorganic contaminations of the river were between SP4 and SP5.
Since the downstream SPs were far from pollution sources and accompanied by other tributaries, the water quality was much better as compared to SP7. At SP8, the concentrations of COD, TN, and TP significantly decreased to lower values of about 14,7 , and $2 \mathrm{mg} / \mathrm{L}$, respectively. Concentrations of DO and SS significantly increased over 8 and $250 \mathrm{mg} / \mathrm{L}$, respectively, which were caused by another tributary import and the increasing of river water quantity. Levels of heavy metals also decreased at SP8: the concentrations of $\mathrm{Pb}, \mathrm{As}, \mathrm{Cu}$, and $\mathrm{Zn}$ in the sediment $(8.2,0.17$,
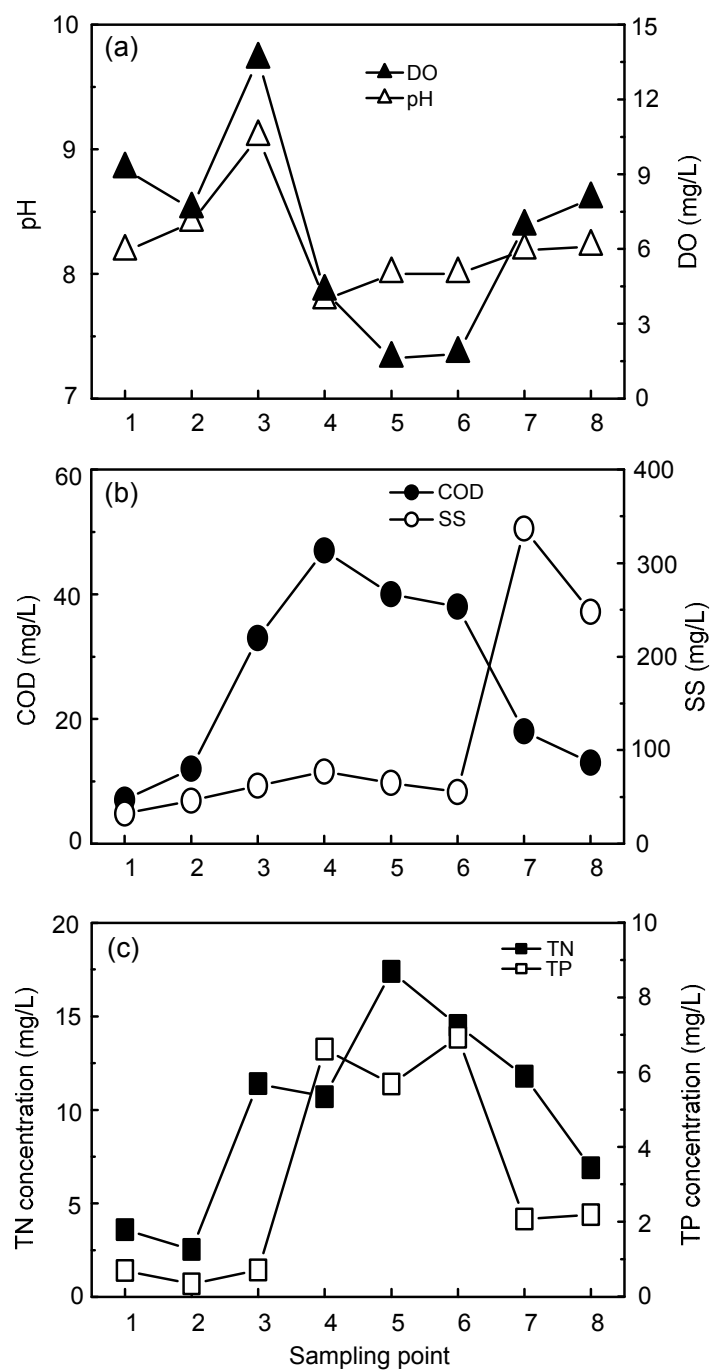

Fig. 3 Water chemistry changes of the Tiaozi River (a) $\mathrm{pH}$ and $\mathrm{DO}$; (b) Chemical oxygen demand (COD) and suspended solid (SS); (c) Total nitrogen (TN) and total phosphate (TP) concentrations. Data are presented as the average of three parallel detections 
Table 1 Distributions of heavy metals in the water and sediment of the Tiaozi River, China

\begin{tabular}{|c|c|c|c|c|c|c|c|c|c|c|c|c|c|c|}
\hline \multirow{2}{*}{$\begin{array}{c}\text { Sampling } \\
\text { point }\end{array}$} & \multicolumn{7}{|c|}{ Water $(\mu \mathrm{g} / \mathrm{L})$} & \multicolumn{7}{|c|}{ Sediment $(\mathrm{mg} / \mathrm{kg})$} \\
\hline & $\mathrm{Cr}$ & $\mathrm{Cd}$ & $\mathrm{Pb}$ & $\mathrm{Hg}$ & As & $\mathrm{Cu}$ & $\mathrm{Zn}$ & $\mathrm{Cr}$ & $\mathrm{Cd}$ & $\mathrm{Pb}$ & $\mathrm{Hg}$ & As & $\mathrm{Cu}$ & $\mathrm{Zn}$ \\
\hline SP1 & 7 & - & - & 0.25 & 0.34 & - & - & 30.1 & 0.04 & 8.8 & 0.33 & 1.12 & 4.6 & 70 \\
\hline $\mathrm{SP} 2$ & 13 & - & - & 0.08 & 0.73 & - & 50 & 32.5 & 0.08 & 11.4 & 0.54 & 1.18 & 18.7 & 707 \\
\hline SP3 & 9 & - & - & 0.08 & 1.85 & - & 211 & 33.8 & 0.08 & 15.4 & 0.89 & 1.13 & 29.2 & 1341 \\
\hline $\mathrm{SP} 4$ & 8 & - & - & 0.1 & 5.72 & - & 420 & 34.1 & 0.12 & 18.6 & 1.22 & 1.92 & 41.3 & 1704 \\
\hline SP5 & 12 & - & - & 0.07 & 4.65 & - & 380 & 33.7 & 0.04 & 16.7 & 1.2 & 0.96 & 37.1 & 1540 \\
\hline SP6 & 9 & - & - & 0.16 & 4.15 & - & 290 & 33.4 & 0.02 & 12.4 & 1.15 & 0.89 & 26.8 & 1020 \\
\hline SP7 & 11 & - & - & 0.08 & 3.81 & - & 170 & 31.2 & - & 6.8 & 0.84 & 0.18 & 3.8 & 1170 \\
\hline SP8 & 5 & - & - & 0.03 & 2.87 & - & 175 & 32.6 & - & 8.2 & 0.76 & 0.17 & 8.5 & 1160 \\
\hline
\end{tabular}

-: concentration below the detection limit. Data are presented as the average of three parallel detections

41.3 , and $1160 \mathrm{mg} / \mathrm{kg}$, respectively) were $44.1 \%$, $8.9 \%, 20.6 \%$, and $68.1 \%$ of their maximum concentrations at SP4, respectively; the dissolved As $(2.87 \mathrm{mg} / \mathrm{L})$ and $\mathrm{Zn}(175 \mathrm{mg} / \mathrm{L})$ were $50.2 \%$ and $41.7 \%$ of those in SP4, respectively.

The midstream and downstream of the Tiaozi River were seriously polluted, and the most serious reaches were between SP4 and SP5, where were from the Siping export to Yihetun, with maximum COD, $\mathrm{TN}$, and TP concentrations of 47, 17.4, and $6.93 \mathrm{mg} / \mathrm{L}$, respectively. Concentrations of $\mathrm{Zn}$ and As were low in the river source, reaching the maximum concentrations of 420 and $5.72 \mu \mathrm{g} / \mathrm{L}$ in the water, and 1704 and $1.92 \mathrm{mg} / \mathrm{kg}$ in the sediment at SP4, respectively, and then decreased in the following reaches. The experimental results of heavy metal contents in different sediment samples indicated that $\mathrm{Zn}$ was the primary metal pollutant discharged from Siping City and its concentration was more than $1000 \mathrm{mg} / \mathrm{kg}$ in the sediments from SP3. Even far away from pollution resources, the sediment at SP8 also had a high concentration of $\mathrm{Zn}(1160 \mathrm{mg} / \mathrm{kg})$. Prolonged pollution has resulted in large amounts of heavy metals being deposited in the river sediment. Although the dissolved heavy metal concentrations complied with the Level III of the Environmental Quality Standard for Surface Water of the China (GB3838-2002), the water polluted by these heavy metals had potential negative effects on aquatic organisms and local people (Chao et al., 2010; Gao et al., 2010). In addition, the large amount of heavy metals deposited in the bed sediments could continually enter the aqueous phase through mutual transformation, thereby extending the time of the river being contaminated.

\subsection{Changes of microbial community diversities in the river sediment}

Community structures of bacteria and fungi at the eight SPs were detected by DGGE (Fig. 4). Diverse bands were excised, sequenced, and compared with the GenBank database (Table S1). The phylogenetic trees of the bacteria and fungus were constructed by the evolutionary distance matrix method (Figs. 5 and 6).

As shown in Fig. 4a, at least 10 bacteria bands were amplified from the sediment at the export of the Xiasantai Reservoir (SP1). The dominant bacteria were Acinetobacter johnsonii (B4), uncultured Clostridiales bacterium (B6), Clostridium cellulovorans (B7), and Clostridium sp. (B14). As the Tiaozi River ran across Siping City, its bacterial community structure changed significantly. From SP3 to SP5, uncultured Sinobacteraceae (B5), Clostridium sp. (B14), and Microbacterium sp. (B16) weakened gradually, and the uncultured Clostridiales bacterium (B6) vanished. Besides A. johnsonii (B4) and C. cellulovorans (B7), Trichococcus pasteurii (B11) appeared and strengthened to be the new dominant bacteria. A. johnsonii, C. cellulovorans, and T. pasteurii were common microorganisms in wastewater and were facultative anaerobe or anaerobe with a certain tolerance to harsh environmental conditions and the removal ability of pollutants (Malik et al., 2003; Lorenz et al., 2006; Xie et al., 2009). There were six dominant bacteria obtained at SP6, while three species, Streptosporangium roseum (B1), Mycobacterium sp. (B8), or uncultured Ruminococcaceae (B12), were not observed at SP5. 
(a)

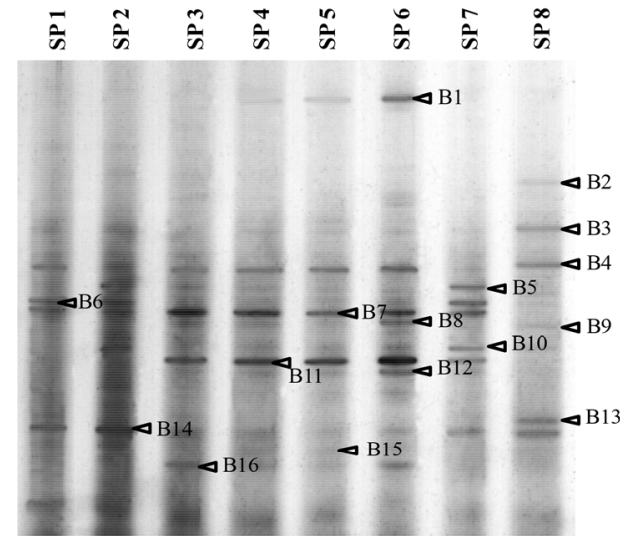

(b)

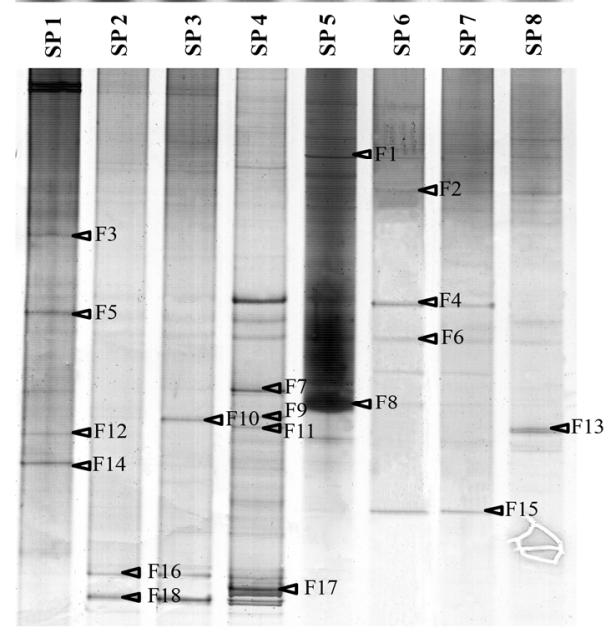

Fig. 4 DGGE profiles of $16 S$ and $18 S$ rRNA genes of different sampling points (SPs)

(a) Bacteria; (b) Fungi. Numbers present bands excised and sequenced

Since the distances between the SPs and the pollution sources and stream injections increased gradually, the pollution degree declined gradually as indicated by the microbial community diversity. Malikia spinosa (B2), Acinetobacter lwoffii (B3), uncultured Sinobacteraceae (B5), Micromonospora sp. (B9), Lactococcus lactis (B10), and Corynebacterium $\mathrm{sp}$. (B13) appeared at SP7 and SP8. A more diverse bacterial community implied that the contaminants in the water such as heavy metals were reduced gradually, followed by the gradual restoration of the self-purification capacity.

Not only fungi were amplified using the primer pairs of NS1 and GC-Fung, but also many protozoan and metazoan. The microbial community structure of eight SPs showed significant differences (Fig. 4b).
The dominants at SP1 were some uncultured eukaryote (F3, F5, F12, F14), but they disappeared in the downstream portion of the river. Candida krissii (F16) and saprophytic of Pythium insidiosum (F18) appeared in SP2 and SP3, which indicated that the river water was contaminated. Protozoan and metazoan of Lepadella patella (F10), Limnodrilus hoffmeisteri (F4, F7, F8), Filinia longiseta (F9), Brachionus calyciflorus (F11), and Lepidosphaeria nicotiae (F17) were detected and strengthened gradually from SP3 to SP6, which implied the increase of the organic pollutants. Although L. hoffmeisteri (F4, F8) could be detected by DGGE, the populations of protozoan and metazoan weakened and gradually vanished in SP7 and SP8. With the gradual recovery of the river water quality from SP6, Nannochloropsis limnetica (F2), Brachionus plicatilis (F15), and Podura aquatic (F13) appeared.

The water pollution of the Tiaozi River had significant effects on the microbial community structure in the river sediment. In the upstream, the water quality was good with diverse microbial species detected in the sediment. The heavy pollution of the river was between SP3 and SP6. The concentrations of COD, TN, TP, especially $\mathrm{Zn}$ and As, were high. Many heavy metals such as $\mathrm{Pb}, \mathrm{Ca}, \mathrm{Cu}, \mathrm{Zn}$, as well as As are common in polluted rivers (Lorenz et al., 2006; Han et al., 2013). Most of the heavy metal ions are deposited in the sediment because of adsorption, hydrolysis, and co-precipitation (Gaur et al., 2005). Ghosh et al. (2004) found that water-soluble forms of As were much more toxic than its insoluble forms. Long-term contamination with heavy metal and As could slow down bacterial growth, alter the soil microbial community composition, and exert a greater inhibitory effect on the enzymes' activities (Ghosh et al., 2004; Lorenz et al., 2006; Zhou et al., 2009; Han et al., 2013; Marabottini et al., 2013).

Although the organic pollutants were abundant, due to the existence of toxic heavy metals such as $\mathrm{Zn}$, only certain bacteria with high tolerance like $A$. johnsonii, C. cellulovorans, and T. pasteurii survived. They grew and reproduced using the organic contaminants in the river water and sediment, but singular bacterial groups resulted in gradual loss of the self-purification capacity of the river. As the sediment contained plentiful organic pollutants and anaerobic 


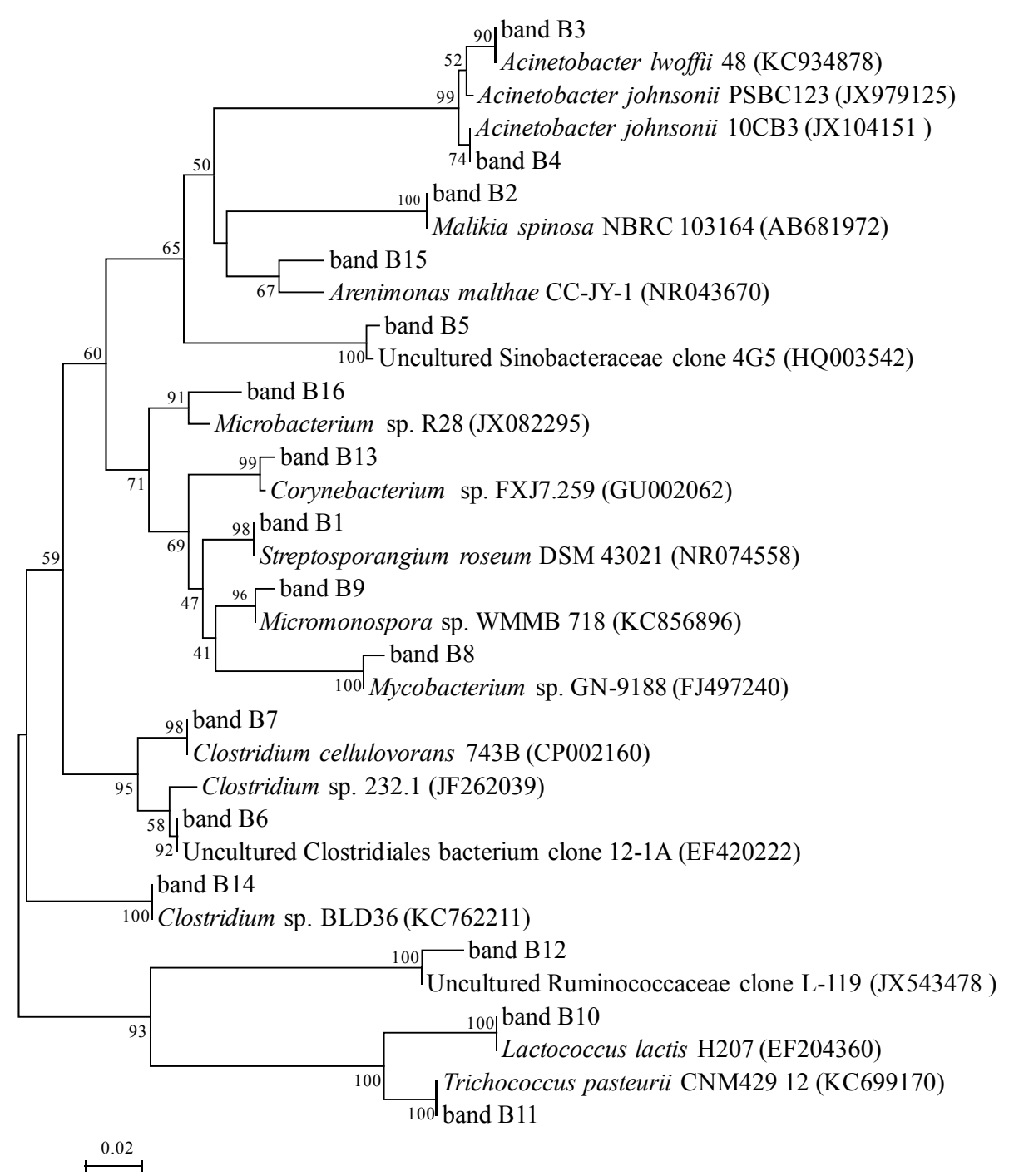

Fig. 5 Phylogenetic tree of DGGE profiles showing the relationships based on an alignment of almost-complete 16S rRNA gene sequences and constructed using the neighbour-joining method

The consensus phylogenetic tree was produced following bootstrap sampling of 1000 datasets. Numbers at nodes indicate percentages of bootstrap support based on a neighbour-joining analysis of 1000 resampled datasets. Bar: 0.02 substitutions per nucleotide position

bacteria, the protozoa and metazoan could utilize them as food for massive growth. However, the protozoa and metazoan were also poisoned by heavy metal, as the species was reduced and mainly consisted of L. patella, F. longiseta, B. calyciflorus, and L. hoffmeisteri. The metazoan of $L$. hoffmeisteri could survive in heavy polluted water, and was quite resistant to heavy metals and other pollutants (Brinkhurst and Kennedy, 1965; Kennedy, 1966; Zhang et al., 2012). On both riverbeds of the Tiaozi River, large red expanses of L. hoffmeisteri mass could be observed between SP4 and SP6 (Fig. 2). The reproduction and growth of the massive L. hoffmeisteri consumed DO, which led to anaerobic fermentation and the water bodies stinking. The aerobic microorganisms have a better metabolic efficiency to the organic pollutants than the anaerobic microorganisms (Maier et al., 2009). The aerobic microorganisms could not grow in water lacking DO, which results in the reduced pollutants degradation ability and the self-purification capacity of the river, and causes a vicious cycle. 


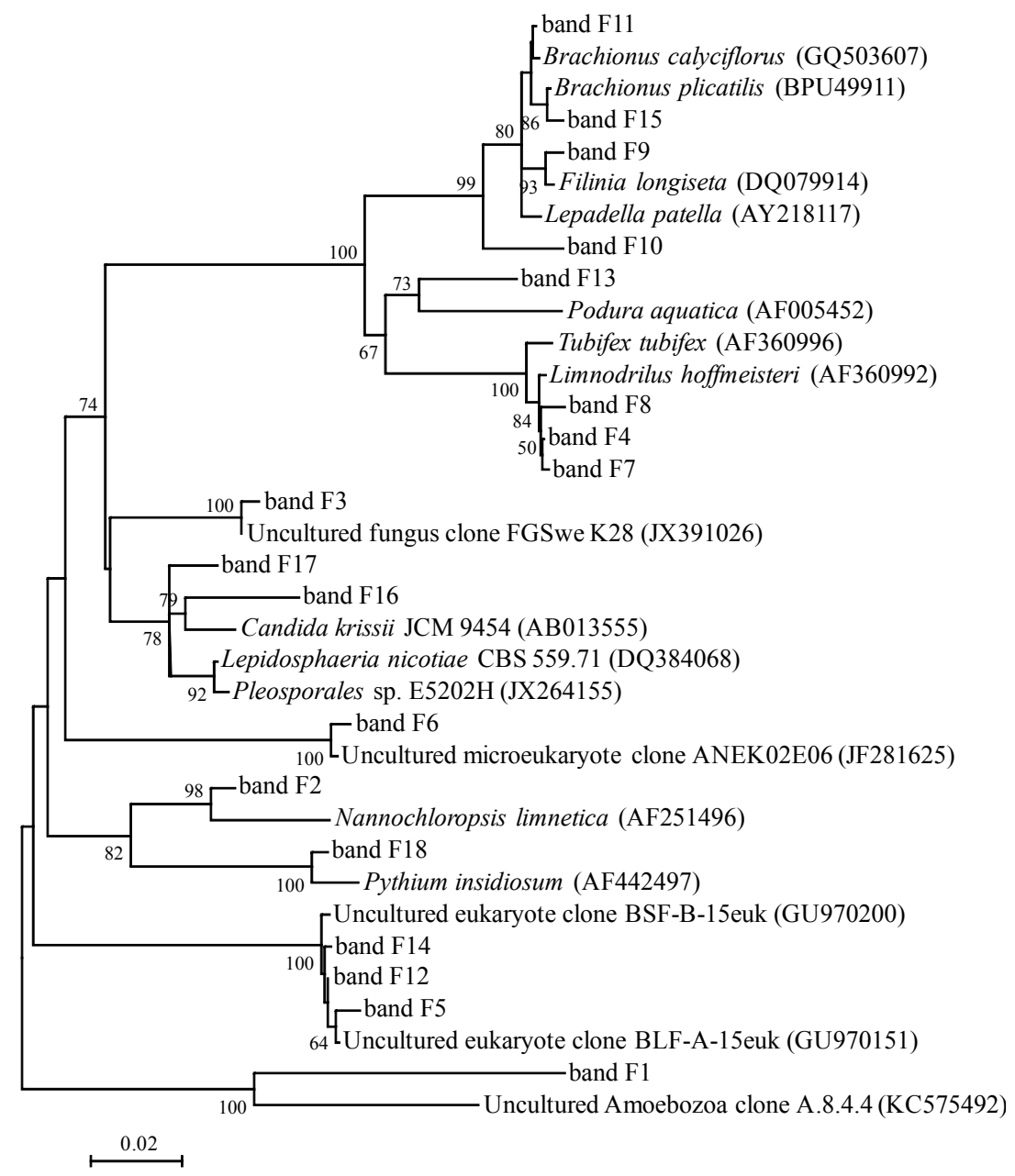

Fig. 6 Phylogenetic tree of DGGE profiles showing the relationships based on an alignment of almost-complete $18 S$ rRNA gene sequences and constructed using the neighbour-joining method

The consensus phylogenetic tree was produced following bootstrap sampling of 1000 datasets. Numbers at nodes indicate percentages of bootstrap support based on a neighbour-joining analysis of 1000 resampled datasets. Bar: 0.02 substitutions per nucleotide position

When the river was far from the pollution sources and tributary injections, the pollutants were gradually diluted and degraded. As a result, the river water quality could be gradually improved, following by the enhancement of the microbial diversity and river self-purification capacity.

\section{Conclusions}

Although the pollutants discharged into the Tiaozi River were significantly reduced with the operation of the Siping City Wastewater Treatment Plant, the pollutants remaining in the river still pose serious threats to its microbial structure. The sediment microbial community structure changed substantially in accordance with the river pollution. The heavy metal ions of $\mathrm{Zn}$ and As were toxic to bacteria, resulted in the extinction of non-resistant bacteria and eukaryotic microbial. L. hoffmeisteri showed a massive growth due to its strong resistance. Therefore, a large amount of DO was consumed and only a few anaerobic bacteria survived, and finally resulted in a weak self-purification capacity of the Tiaozi River.

The microbial community composition and diversity are sensitive indicators to water pollution. The monitoring results of the microbial communities in river sediments by DGGE help us to understand in-depth the river's pollution status and provide assistance for the management of polluted rivers. 


\section{Compliance with ethics guidelines}

Jun ZHAO, Xin ZHAO, Lei CHAO, Wei ZHANG, Tao YOU, and Jie ZHANG declare that they have no conflict of interest.

This article does not contain any studies with human or animal subjects performed by any of the authors.

\section{References}

American Public Health Association (APHA), 1998. Standard Methods for the Examination of Water and Wastewater, 20th Ed. Washington DC, USA.

Bassam, B.J., Caetano-Anollés, G., Gresshoff, P.M., 1991. Fast and sensitive silver staining of DNA in polyacrylamide gels. Anal. Biochem., 196(1):80-83. [doi:10.1016/ 0003-2697(91)90120-I]

Brandt, K.K., Frandsen, R.J.N., Holm, P.E., et al., 2010. Development of pollution-induced community tolerance is linked to structural and functional resilience of a soil bacterial community following a five-year field exposure to copper. Soil Biol. Biochem., 42(5):748-757. [doi:10. 1016/j.soilbio.2010.01.008]

Brinkhurst, R.O., Kennedy, C.R., 1965. Studies on the biology of the Tubificidae (Annelida, Oligochaeta) in a polluted stream. J. Anim. Ecol., 34(2):429-443. [doi:10.2307/2659]

Chao, L., Chen, S., Dai, X., et al., 2010. Assessment on water environment status of surface water in typical country river-Tiaozi River. Heilongjiang Agric. Sci., 2010(11): 53-56 (in Chinese).

Chen, B., 2009. Discussion on harm of polluted Tiaozi River and Zhaosutai River to drinking water for people and livestocks in Changtu County. Environ. Protection Sci., 35(1):45-47 (in Chinese).

Cooke, J.A., Andrew, S.M., Johnson, M.S., 1990. Lead, zinc, cadmium and fluoride in small mammals from contaminated grass-land established on fluorspar tailings. Water Air Soil Pollut., 51(1-2):43-54. [doi:10.1007/BF00211502]

Deniseger, J., Erickson, J., Austin, A., et al., 1990. The effects of decreasing heavy metal concentrations on the biota of Buttle Lake, Vancouver Island, British Colimbia. Water Res. 24(4):403-416. [doi:10.1016/0043-1354(90)90222-R]

Gao, C.F., Zhao, J., Lang, X.M., et al., 2010. Applied research on artificial strengthen ecological filter bed technology for the improvement of the water in Tiaozihe River project. $J$. Anhui Agric. Sci., 38(30):17006-17008 (in Chinese).

Garcia-Armisen, T., Vercammen, K., Passerat, J., et al., 2011. Antimicrobial resistance of heterotrophic bacteria in sewage-contaminated rivers. Water Res., 45(2):788-796. [doi:10.1016/j.watres.2010.09.003]

Gaur, V.K., Gupta, S.K., Pandey, S.D., et al., 2005. Distribution of heavy metals in sediment and water of River Gomti. Environ. Monit. Assess., 102(1-3):419-433. [doi:10.1007/s10661-005-6395-6]

GB3838-2002. Environmental Quality Standard for Surface Water. State Standards of People's Republic of China, Beijing, China.

Ghosh, A.K., Bhattacharyya, P., Pal, R., 2004. Effect of arse- nic contamination on microbial biomass and its activities in arsenic contaminated soils of Gangetic West Bengal, India. Environ. Int., 30(4):491-499. [doi:10.1016/j.envint. 2003.10.002]

Goberna, M., Insam, H., Klammer, S., et al., 2005. Microbial community structure at different depths in disturbed and undisturbed semiarid Mediterranean forest soils. Microb. Ecol., 50(3):315-326. [doi:10.1007/s00248-005-0177-0]

Green, J.L., Bohannan, B.J.M., Whitaker, R.J., 2008. Microbial biogeography: from Taxonomy to traits. Science, 320(5879):1039-1043. [doi:10.1126/science.1153475]

Han, J., Liu, Y., Liu, X., et al., 2013. The effect of continuous $\mathrm{Zn}$ (II) exposure on the organic degradation capability and soluble microbial products (SMP) of activated sludge. $J$. Hazard. Mater., 244-245:489-494. [doi:10.1016/j.jhazmat. 2012.10.065]

Jiang, H., Zou, L., Li, X., et al., 2002. Circumstance assessment of eco-geological environment in Siping district. $J$. Jilin Univ., 32(1):87-91 (in Chinese).

Kennedy, C.R., 1966. The life history of Limnodrilus hoffmeisteri CLAP (Oligochaeta, 551 Tubificidae) and its adaptive significance. Oikos, 17(2):158-168. [doi:10. 2307/3564940]

Lorenz, N., Hintemann, T., Kramarewa, T., et al., 2006. Response of microbial activity and microbial community composition in soils to long-term arsenic and cadmium exposure. Soil Biol. Biochem., 38(6):1430-1437. [doi:10. 1016/j.soilbio.2005.10.020]

Maier, R.M., Pepper, I.L., Gerba, C.P., 2009. Environmental Microbiology, 2nd Ed. Elsevier Inc., Academic Press, USA.

Malik, A., Sakamoto, M., Ono, T., et al., 2003. Coaggregation between Acinetobacter johnsonii S35 and Microbacterium esteraromaticum strains isolated from sewage activated sludge. J. Biosci. Bioeng., 96(1):10-15. [doi:10. 1016/S1389-1723(03)90090-9]

Marabottini, R., Stazi, S.R., Papp, R., et al., 2013. Mobility and distribution of arsenic in contaminated mine soils and its effects on the microbial pool. Ecotoxicol. Environ. Saf., 96:147-153. [doi:10.1016/j.ecoenv.2013.06.016]

May, L.A., Smiley, B., Schmidt, M.G., 2001. Comparative denaturing gradient gel electrophoresis analysis of fungal communities associated with whole plant corn silage. Can. J. Microbiol., 47(9):829-841. [doi:10.1139/w01-086]

Ministry of Environmental Protection of the People's Republic of China (MEP), 2013. 2012 China Environment Bulletin. Available from http://jcs.mep.gov.cn/hjzl/zkgb/2012zkgb/ [Accessed on Dec. 5, 2013].

Proia, L., Lupini, G., Osorio, V., et al., 2013. Response of biofilm bacterial communities to antibiotic pollutants in a Mediterranean river. Chemosphere, 92(9):1126-1135. [doi:10.1016/j.chemosphere.2013.01.063]

Ren, N., Xing, D., Rittmann, B.E., et al., 2007. Microbial community structure of ethanol type fermentation in bio-hydrogen production. Environ. Microbiol., 9(5): 1112-1125. [doi:10.1111/j.1462-2920.2006.01234.x] 
Sin, S.N., Chua, H., Lo, W., et al., 2001. Assessment of heavy metal cations in sediments of Shing Mun River, Hong Kong. Environ. Int., 26(5):297-301. [doi:10.1016/S01604120(01)00003-4]

Sun, M.Y., Dafforn, K.A., Brown, M.V., et al., 2012. Bacterial communities are sensitive indicators of contaminant stress. Mar. Pollut. Bull., 64(5):1029-1038. [doi:10.1016/ j.marpolbul.2012.01.035]

Tian, Y., Liu, H., Zheng, T., et al., 2008. PAHs contamination and bacterial communities in mangrove surface sediments of the Jiulong River Estuary, China. Mar. Pollut. Bull., 57(6):707-715. [doi:10.1016/j.marpolbul.2008.03.011]

Virsek, M.K., Hubad, B., Lapanje, A., 2013. Mercury induced community tolerance in microbial biofilms is related to pollution gradients in a long-term polluted river. Aquat. Toxicol., 144-145:208-217. [doi:10.1016/j.aquatox.2013. 09.023]

Xie, S., Liu, J., Qiao, C., 2009. Biodegradation of malathion by Acinetobacter johnsonii MA19 and optimization of cometabolism substrates. J. Environ. Sci., 21(1):76-82. [doi:10.1016/S1001-0742(09)60014-0]

Yan, D., Deng, W., Wang, J., et al., 2000. A study on content of heavy metal in sediment of Tiaozi River. Bull. Soil Water Conserv., 20:29-31 (in Chinese).

Yang, X., Chen, S., Chao, L., et al., 2012. Pollution characteristics and assessment of heavy metals in Tiaozi River sediments. J. Anhui Agric. Sci., 40(4):2147-2150 (in Chinese).

Yuan, X., Qian, X., Zhang, R., et al., 2012. Performance and microbial community analysis of a novel bio-cord carrier during treatment of a polluted river. Bioresour. Technol., 117:33-39. [doi:10.1016/j.biortech.2012.04.058]
Zhang, X., Tian, Y., Wang, Q., et al., 2012. Heavy metal distribution and speciation during sludge reduction using aquatic worms. Bioresour. Technol., 126:41-47. [doi:10. 1016/j.biortech.2012.09.015]

Zhao, X., Xing, D., Zhang, L., et al., 2010. Characterization and over expression of a $[\mathrm{FeFe}]$-hydrogenase gene of a novel hydrogen-producing bacterium Ethanoligenens harbinense. Int. J. Hydrogen Energy, 35(18):9598-9602. [doi:10.1016/j.ijhydene.2010.06.098]

Zhao, X., Xing, D., Liu, B., et al., 2012. The effects of metal ions and L-cysteine on hydA gene expression and hydrogen production by Clostridium beijerinckii RZF-1108. Int. J. Hydrogen Energy, 37(18):13711-13717. [doi:10. 1016/j.ijhydene.2012.02.144]

Zhou, Y., Yao, J., Choi, M.M.F., et al., 2009. A combination method to study microbial communities and activities in zinc contaminated soil. J. Hazard. Mater., 169(1): 875-881. [doi:10.1016/j.jhazmat.2009.04.027]

Zhu, J., Zhang, J., Li, Q., et al., 2013. Phylogenetic analysis of bacterial community composition in sediment contaminated with multiple heavy metals from the Xiangjiang River in China. Mar. Pollut. Bull., 70(1):134-139. [doi:10. 1016/j.marpolbul.2013.02.023]

\section{List of electronic supplementary materials}

Table S1 Phylogenetic affiliations of bacteria and eukaryotes from eight samples based on $16 \mathrm{~S}$ and $18 \mathrm{~S}$ rRNA sequences

\section{中文瀶要:}

本文题目: 中国东北条子河中微生物群落变化与锌砷污染的关系研究

Diversity change of microbial communities responding to zinc and arsenic pollution in a river of northeastern China

研究目的：通过研究河流微生物与污染物的互作关系，为河流污染治理等相关研究提供新途径。

创新要点: 研究选择的目标河流是报道较少的辽河二级支流, 该研究对于了解支流污染特别是东北地区河 流污染有重要的意义。将分子生态学技术应用于分析不同污染程度的河流底泥微生物变化, 建 立微生物种群变化和污染物的互作关系。

研究方法：选取沿条子河的 8 个代表性区段，分析河水和底泥中重金属和污染物的变化情况。通过变性梯 度凝胶电泳（DGGE）技术分析不同河流区段内真核和原核微生物种群变化, 解析河流中污染 物对底泥微生物的影响, 建立微生物种群变化和重金属污染的互作关系。

重要结论：重金属污染物的存在能抑制底泥中微生物生长，仅少量具有较强抗性的微生物存活（见图4）; 有机污染物的增加使对重金属有较强抗性的 Limnodrilus hoffmeisteri 大量繁殖（见图2 4)，从 而大量消耗溶解氧, 导致好氧微生物死亡和河水自净能力退化, 最终引起水质恶化。由此可见, 微生物对环境污染物的变化有很敏感的响应, 通过对环境中微生物的监测有助于进一步分析环 境污染的变化。

关键词组：河流污染；微生物群落结构；变性梯度凝胶电泳（DGGE）; 重金属; 锌; 砷 